\author{
Inge de Koning \\ Pieter A. van Doorn \\ Hugo R. van Dongen
}

\section{Slowly progressive \\ isolated dysarthria: longitudinal course, speech features, and neuropsychological deficits}

Received: 29 April 1997

Received in revised form: 22 August 1997 Accepted: 25 August 1997

Sirs: Dysarthria can be the first sign of a neurological disease. In the initial phase it can be difficult to differentiate dysarthria from other (acquired) speech disturbances, especially if the speech problem remains mild and isolated for a long period. We describe the course of a slowly progressive dysarthria in relation to motor deficits mainly limited to the speech musculature in a patient who proved to have primary lateral sclerosis (PLS).

In 1992, a 72-year-old healthy woman visited our department with the complaint of a persistent speech problem, which - in her view - had started immediately after the death of her husband in 1988. However, later on relatives unanimously reported a gradual onset of speech problems 1 year before this event. As speech therapy was not effective, she was referred to a neurologist elsewhere in 1990, but as neurological examination and CT showed no abnormality the speech disturbance was considered to be psychogenic.
Full neurological re-examination revealed no abnormality, except for dysarthric signs (see Table 1 for the course of dysarthria [3] and motor deficits of the speech musculature). $\mathrm{CT}$ and laboratory investigation, including complete blood count, TSH, copper, ceruloplasmin, very long chain fatty acid ratios and arylsulphatase levels were normal, and antibodies against acethylcholinreceptors were absent. Neuropsychological examination demonstrated an IQ within the normal range $(25-50$ th percentile) [8]; there were no signs of memory disorders or aphasia. In 1994, neurological examination only revealed a bilateral positive palmomental reflex. Cranial MRI was normal.

In 1995, pathological brainstem reflexes and a Babinski sign on the left side were present. Extended EMG examination, including the tongue, revealed no denervation potentials or any other abnormalities. Brain MRI showed one lacunar infarct in the right cerebral peduncle. SPECT revealed bilaterally reduced activity preferentially in the basal motor cortex with normal activity at the level of the brainstem nuclei. The diagnosis of PLS was made as the patient fulfilled the diagnostic criteria proposed by Pringle et al. [7].

In September 1995, neuropsychological examination still showed a normal intelligence (50-75th percentile) [8]. She was well oriented without manifest memory disorder, aphasia, or apraxia. However, she had problems with concept shifting, generating new ideas, planning and organizing. Behaviour at testing was slightly impulsive [1]. Based on these results, it was concluded that there were mild frontal lobe deficits.
In January 1996 the patient could only communicate with paper and pencil; she no longer attempted to speak. She had major problems with swallowing and chewing owing to severe weakness of the tongue. Despite the anarthria and concomitant problems the patient still lived independently and communicated with her relatives by telefax.

Slowly progressive, isolated speech disorders have been known since Mesulam et al. [6] reported on primary progressive aphasia. However, a primary progressive pseudobulbar dysarthria has not been explicitly reported before. Nevertheless, this phenomenon is known $[4,5]$. Probably the course of slowly progressive dysarthria has never been analysed, because in most of the reported patients the onset of the dysarthria was relatively mild and the patients consulted a neurologist only when concomitant motor deficits were distinctively present. The pathological abnormalities in patients with PLS are limited to the precentral motor cortex and the corticospinal tracts [7]. In the patient we describe frontal lobe dysfunction is suggested by the local hypoperfusion on the SPECT scan and is supported by the neuropsychological findings in 1995, similar to the findings by Caselli et al. in patients with PLS [2].

In conclusion, an unclassifiable speech disturbance with an insidious onset and a slow course without neurological concomitant signs suggests a psychogenic cause, but long-term follow-up may reveal a neurological disorder. In our patient, dysarthria was the first and only sign of PLS for 5 years. 
Table 1 Perceptual analysis of the patient's dysarthric speech in relation to the motor deficits of the speech musculature a > Increasing severity of speech dimension compared to previous years [3]; - no abnormalities, + mild involvement,

++ severe involvement, +++ impossible

\begin{tabular}{|c|c|c|c|c|c|}
\hline & 1992 & 1993 & 1994 & 1995 & 1996 \\
\hline \multicolumn{6}{|c|}{ Perceptual analysis of the dysarthric speech $\mathrm{a}$} \\
\hline Articulation & $\begin{array}{l}\text { Imprecise } \\
\text { consonant } \\
\text { clusters }\end{array}$ & $\begin{array}{l}>\text { Imprecise } \\
\text { consonant } \\
\text { clusters }\end{array}$ & $\begin{array}{l}>\text { Imprecise } \\
\text { consonants }\end{array}$ & $\begin{array}{l}\text { > Imprecise } \\
\text { consonants } \\
\text { Vowels } \\
\text { distorted, } \\
\text { phonemes pro- } \\
\text { longed }\end{array}$ & $\begin{array}{l}\text { Unintelligible } \\
\text { speech }\end{array}$ \\
\hline Voice quality & $\begin{array}{l}\text { Monotonous } \\
\text { volume }\end{array}$ & $\begin{array}{l}\text { Monotonous } \\
\text { volume and } \\
\text { pitch } \\
\text { strained, } \\
\text { strangled voice }\end{array}$ & $\begin{array}{l}\text { > Monotonous } \\
\text { volume and } \\
\text { pitch } \\
\text { harsh voice }\end{array}$ & $>$ harsh voice & $>$ harsh voice \\
\hline \multicolumn{2}{|l|}{ Respiration } & & Audible & $\begin{array}{l}>\text { Audible } \\
\text { forced in- } \\
\text { expiration }\end{array}$ & $\begin{array}{l}>\text { Audible } \\
>\text { forced in- } \\
\text { expiration }\end{array}$ \\
\hline \multirow[t]{2}{*}{ Prosody } & & $\begin{array}{l}\text { Variable rate } \\
\text { of speech }\end{array}$ & $\begin{array}{l}\text { Slow speech } \\
\text { rate }\end{array}$ & $\begin{array}{l}\text { > Slow speech } \\
\text { rate }\end{array}$ & $\begin{array}{l}\text { Reduced } \\
\text { stress }\end{array}$ \\
\hline & & & $\begin{array}{l}\text { Short phrases, } \\
\text { intervals pro- } \\
\text { longed }\end{array}$ & $\begin{array}{l}\text { >> Intervals } \\
\text { prolonged }\end{array}$ & $\begin{array}{l}\text { February: } \\
\text { no speech } \\
\text { possible }\end{array}$ \\
\hline \multicolumn{6}{|c|}{ The course of motor deficits of the speech musculature } \\
\hline N. II, IV, VI & - & - & - & - & - \\
\hline \multicolumn{6}{|l|}{ N. V } \\
\hline Open jaw & - & - & - & - & +++ \\
\hline Close jaw & - & - & - & - & + \\
\hline Shake jaw & - & - & - & +++ & +++ \\
\hline Chewing & - & - & - & + & +++ \\
\hline Sensory & - & - & - & - & - \\
\hline \multicolumn{6}{|l|}{ N. VII } \\
\hline $\begin{array}{l}\text { Wrinkle } \\
\text { forehead }\end{array}$ & - & - & - & - & +++ \\
\hline Closure of eyes & - & - & - & + & ++ \\
\hline Spreading lips & - & + & + & ++ & +++ \\
\hline Tingling lips & - & - & - & ++ & +++ \\
\hline Blowing & - & - & - & ++ & +++ \\
\hline Facial mimicry & - & - & - & + & ++ \\
\hline N. VIII & - & - & - & - & - \\
\hline \multicolumn{6}{|l|}{ N. IX, X } \\
\hline $\begin{array}{l}\text { Elevation } \\
\text { palatum }\end{array}$ & - & - & - & - & - \\
\hline Swallowing & - & - & - & + & ++ \\
\hline N. XI & - & - & - & - & - \\
\hline \multicolumn{6}{|l|}{ N. XII } \\
\hline \multicolumn{6}{|l|}{ Tongue: } \\
\hline Atrophy & - & - & - & - & - \\
\hline Fasciculations & - & - & - & - & - \\
\hline Protrusion & - & - & - & + & ++ \\
\hline Upward & - & - & - & +++ & +++ \\
\hline Downward & - & - & - & +++ & +++ \\
\hline Lateral & - & + & + & ++ & +++ \\
\hline
\end{tabular}




\section{References}

1. Bechara A, Damasio H, Tranel D, Damasio AR (1997) Deciding advantageously before knowing the advantageous strategy. Science 275: 1293-1295

2. Caselli RJ, Smith BE, Osborne D (1995) Primary lateral sclerosis: a neuropsychological study. Neurology 45: 2005-2009

3. Darley FL, Aronson AE, Brown JK (1969) Differential diagnostic patterns of dysarthria. J Speech Hear Res 12: 246-269

4. Fisher CM (1977) Pure spastic paralysis of corticospinal origin. Can J Neurol Sci 4: $251-258$

5. Gastaut JL, Michel B, Figarella-Branger D, Somma-Mauvais H (1988) Chronic progressive spinobulbar spasticity. A rare form of primary lateral sclerosis. Arch Neurol 45: 509-513

6. Mesulam MM (1987) Primary progressive aphasia - differentiation from Alzheimer's disease. Ann Neurol 22: 533534

7. Pringle CE, Hudson AJ, Munoz DG, Kiernan JA, Brown WF, Ebers GC (1992) Primary lateral sclerosis. Clinical features, neuropathology and diagnostic criteria. Brain 115: 495-520

8. Raven JC (1965) Guide to using the coloured progressive matrices. Lewis, London

I. de Koning - P. A. van Doorn

H. R. van Dongen ( $\triangle)$

Department of Neurology,

University Hospital Rotterdam-Dijkzigt,

dr. Molewaterplein 40,

3015 GD Rotterdam, The Netherlands

\section{Kevin Crofts \\ Rosie Brennan \\ Peter Kearney \\ Gerard O'Connor}

\section{Vigabatrin-induced optic neuropathy}

Received: 31 January 1997

Received in revised form: 17 July 1997

Accepted: 1 August 1997

Vigabatrin [7] may have an important role in the treatment of seizures in tuberous sclerosis, as well as being a helpful anticonvulsant in other epileptic conditions. The reported side-effects of vigabatrin are central nervous system-related and mainly of a behavioural nature. Visual complaints such as diplopia and constriction of visual fields have been noted. We report a child with partial seizures and secondary generalisation who developed optic neuritis while taking vigabatrin.

An 8-year-old girl presented with episodes of pain and twitching in the right lower limb, which at times progressed to a generalised tonic clonic seizure. The initial EEG was normal, but video telemetry confirmed the clinical diagnosis of partial epilepsy with secondary generalisation. CT and MRI findings were normal. The patient was initially treated with carbamazepine without effect. She subsequently improved on valproate 400 $\mathrm{mg}$ b.i.d. The focal episodes recurred with twitching of the right face and neck associated with loss of speech. Vigabatrin (Sabril, Marion Merrell Dow Ltd) $500 \mathrm{mg}$ nocte was added to valproate $400 \mathrm{mg}$ b.i.d. Two days after starting the vigabatrin she was unable to speak. She subsequently said that she knew what she wanted to say but could not get the words out. She was also unable to read. The parents discontinued the vigabatrin as they felt she was having some sort of reaction to the drug. Two days later she was well again and was referred for a paediatric neurology opinion. She had further episodes of trace-like states and associated dysphasia. The Landau-Klaffner syndrome was considered, but the final assessment was partial complex seizures. She was recommenced on vigabatrin $125 \mathrm{mg}$ b.i.d. and valproate $400 \mathrm{mg}$ b.i.d. She remained stable without seizures for 6 months, when she developed a tremor of her right hand. The vigabatrin was increased to $375 \mathrm{mg} /$ day. She remained well for a further 3 months when she developed pain over her left eye for 1 day. She had no systemic symptoms, no rash, and had not received any immunisations recently. On routine review 6 months later she was referred for an ophthalmological opinion because of disc pallor. Her full blood court was normal and intradermal allergen testing was negative.

Opthalmology examination revealed a visual acuity of "hand movements" in the right eye and $6 / 18$ in the left eye. There was a right afferent pupillary defect and red desaturation on colour vision testing. Fundoscopy confirmed bilateral optic disc pallor. Electrodiagnostic tests showed an abnormal pattern visually evoked response (VER) bilaterally. The VER on the right was almost absent with no recordable peak. On the left there was a delayed latency to $163.5 \mathrm{~ms}$. Electrooculography was normal with normal Arden ratios. Electroretinography was normal with normal oscillatory potentials. Vigabatrin was stopped. Treatment included dexamethosone IV and Pabrinex IV. Six weeks later her visual acuity had improved to $6 / 24$ on the right and $6 / 12$ on the left. Five months following her initial presentation her visual acuity had improved to 6/9 bilaterally. Her VER had improved markedly with a latency of $153 \mathrm{~ms}$ on the right and 147 ms on the left. MRI showed no evidence of demyelination. 